\title{
ISO 14001 Çevre Yönetim Sistemi (ÇYS) Standardı : Türkiye'deki Bazı İşletmelerin Karşılaştıkları Problem ve Zorluklar Üzerine Bir Araştırma
}

\section{ISO 14001 Envionmental Management System (EMS) Standard: A Study on The Barriers and Problems Faced by Some Enterprises in Turkey}

\author{
Bengü MINDIKOĞLU ${ }^{1}$, A. Ergin DUYGU ${ }^{2}$ \\ ${ }^{1}$ KKTC Başbakanlık Kıbrıs Türk Yatırım Geliştirme Ajansı (YAGA), Lefkoşa KKTC \\ bengum@yahoo.com \\ ${ }^{2}$ Ankara Üniversitesi Fen Fakültesi Biyoloji Bölümü, Tandoğan, Ankara \\ A.Ergin.Duygu@science.ankara.edu.tr
}

\begin{abstract}
Özet: Bu çalışmada, işletmelerin ISO 14001 ÇYS'nin kurulum ve işletim aşamalarında yaşadıkları problem ve zorluklar ile etki derecelerinin ortaya konulması, ayrıca kurulumunu planlayan işletmelere rehber teşkil edebilecek bilgiler sunulması hedeflenmiştir. $\mathrm{Bu}$ amaçla Türkiye genelinde 62 işletmenin katıldığı bir anket çalışması yapılmıştır. Anket sorularının hazırlanmasında uluslararası literatürde yer alan genel sorun ve zorluklar yanında, Türkiye'de önceki yıllarda hazırlanan tez çalışmalarından yararlanılmıştır. Elde edilen sonuçlar 'Excel' ve SPSS paket programları ile analiz edilmiştir. Anket sonuçlarının literatürde belirlenenler ile paralellik gösterdiği, ancak hissedilme sıklık ve derecelerinde farklılıklar olduğu gözlemlenmiştir. Anket çalışması neticesinde görülen problem ve zorluklardan en baskın olanları; "çevre ile ilgili konulardaki alt yapı yetersizliği”, "atık gideriminde lisanslı, uygun alanların bulunamaması", "devletin ve ilgili kurumların destek ve teşviklerinin yeterli olmaması" şeklinde belirlenmiştir. Bu sonuçlar literatürde verilenlerle karşılaştırılarak tartışılmıştır. Sonuç olarak başta bu sorunlar olmak üzere, belirlenen tüm problemlerin çözümü için, toplumun her düzeyinde işlevsel çevre bilincinin oluşturulması ve arttırılmasının, çevre yönetimi alt yapısının oluşturulması ve çevreci yaklaşımların yönetsel düzeyde desteklenmesinin çok önemli ve gerekli olduğu görülmüştür.
\end{abstract}

Anahtar kelimeler: ISO 14001, ÇYS.

Abstract: In this research, it was aimed to determine the barriers and problems that enterprises face with during the setup and the management phases of the ISO 14001 EMS, also to constitute a guide for the enterprises at planning stage. A survey was conducted with the participation of 62 enterprises in Turkey,. covering questions on the barriers and the problems, as designed in reference to similar examples reported in the international published literature and the previous thesis completed. Results obtained by the survey were analysed by using Excel and SPSS programs. Although the frequencies and the levels of the significance of the barriers and problems were different from the ones that were identified in the literature, there was a qualitative parallellism between the present and previously reported ones in the literature. The most dominant problems determined through the presented survey were: "Poor environmental infrastructure", "insufficcient number of licensed waste disposal sites", and "insufficient incentives and support given by related departments" respectively. The presented results are comparatively discussed with the ones reported in the literature. It has been concluded that, creation and raising the functional environmental community consciousness at all stages was very important and necessary to surmount these major and other problems determined in this study

Key words: ISO 14001, EMS.

\section{Giriş}

$\mathrm{Bu}$ çalışmada amaç, literatürde yer alan ISO 14001 ÇYS'nde dünya genelinde yaşanılan problem ve zorluklar ışı̆̆ında hazırlanan anket çalışması ile Türkiye örneğinde yaşanılanları belirlemektir. Yapılan değerlendirmede sorunların aşılma durumu, işletmelerin çalışma konusu, personel sayısı, bulundukları şehirler, işletmelerin sertifikalandırılma amaçları, bu amaçlara ulaşılıp ulaşılamadıkları, belgelendirme süreci, süresi ve danışman gereksinimi gibi konular da saptanmış ve dikkate alınmıştır. Daha önceki çalışmalara bakıldığında, Türkiye genelinde ISO 14001'de yaşanılan problem ve zorlukların geniş kapsamda araştırılmadığı, daha çok ISO 14001'in farklı sektörlerdeki uygulama örnekleri ile standardın yararlarına ağırlık verilmiş olduğu görülmüştür. Bunlar arasında Polat (2003) ÇYS'lerinin işletmelere faydaları, Cevilan (2003) kağıt, Tuna (2003) otomotiv, Demirhan (2002) un, Usta (2001) çay, Odabaşı (2001) tekstil, Erdağ (2000) cam, Uzun (1999) elektronik, Karali (2002) gida, Ulu (2001) kablo, Tunca (2001) ilaç, Çelebi (1999) polimerik şerit elyaf sektörleri üzerine yapılmış çalışmalar ile Zığındere (1999) Arçelik, ve Doğan (2002) petrol istasyonu örnekleri yer almaktadır. Ancak kısmen dahi olsa Yüksel (2002) ve Atıcı (1999)'nın ISO 14001 konusunda 
yaşanılan sorun ve zorluklara değindiği görülmüştür. Bu çalışma, belirtilen ve benzeri yayınlarda eksikliği görülmüş olan bu konunun irdelenmesinin işletmelere sağlayabileceği yararlar düşünülerek hazırlanmıştır. Çalışmada temel olarak, Türkiye'de işletmelerin ISO 14001 ÇYS kurma ve işletme aşamalarında karşılaş̧ırkları problem ve zorluklar araştırılmıştır.

\section{Materyal ve Yöntem}

Anket formu daha önce ISO 14001 üzerine hazırlanan tez çalışmalarında kullanılan anket formları ve formatları (Karakaş, 2002; Yüksel, 2002; Demirel, 2001; Tütün, 2000) yanında, literatür taramasında edinilen ve tartışma bölümünde referansları belirtilen çalışmalardan derlenen bilgiler ışığında hazırlanmıştır. Sorular, elde edilen form örnekleri doğrultusunda ve katılımcıların harcayacağı zamanı en az seviyede tutabilmek adına, açık uçlu sorular yerine olabildiğince kısa cevaplı ve potansiyel yanıtların seçeneklendirilmesine dikkat edilerek düzenlenmiştir (Mındıkoğlu, 2007). Anket formunun uygunluk değerlendirmesinde, özel sektörde konu ile ilgili danışmanlık ve eğitmenlik hizmeti veren Kadir Öztaş'ın da değerli görüşlerine yer verilmiştir. 20 sorudan oluşan formun "Açıklamalar" bölümünde form içeriği, kullanım amacı ve kalitesinin bilimsel açıdan önemi açıklanmıştır. "İşletmeye ait genel bilgiler" bölümünde etki analizinde kullanılmak üzere işletmenin sektörü, personel sayısı, bulunduğu kent, coğrafi bölge ve iletişim bilgileri gibi genel bilgiler istenmiştir. Anket soruları kapsamında ISO 14001 ÇYS sorun ve zorlukları ile aşılma durumlarının belirlenmesine yönelik sorular yanında, sertifikalandırmanın amacı, süresi ve süreci, standardın aksayan yönleri, danı̧̧man gereksinimi gibi konular yer almıştır. Örneklem Türkiye'deki ISO 14001 ÇYS belgesine sahip işletmelerden oluşmuştur. Bu belgeye sahip işletmelerin tek ve ortak bir listesi bulunamadığından, Türkiye Kalite Derneği "KalDer", Türk Standartları Enstitüsü "TSE", diğer belgelendirme kuruluşları ve internet araştırmalarıyla bir liste oluşturulmuştur. Anket çalışması 2006 y1lında gerçekleştirilmiştir. Uygulama, ISO 14001 ÇYS belgesine sahip olup iletişim kurulan 120 işletmenin 62'sinden sağlanan geri dönüşlerle tamamlanmıştır. Nicel araştırma yöntemiyle anket formunun iletilmesi ve geri dönüşü sonucunda elde edilen bulgular değerlendirilmiştir. Analiz ve görselleştirme 'Excel' ve 'SPSS' sosyal bilimler istatistik paket programıly yapılmıştır. Etki analizlerinde bağımsız sorular arası anlamlılık sorgulamasında anlamlılık düzeyi $\mathrm{p}<0.05$ olarak kabul edilmiştir.

\section{Bulgular}

Aşağıda ankete katılan işletmelerin personel sayıları, sektörel dağılımları, katıldıkları kent ve coğrafi bölge bilgileri verilmiştir. Bu bilgiler etki analizinin anlamlılık sorgulamasında kullanılmıştır.

Katılımcı işletmelerin personel sayıları, 2005/9617 karar sayılı "Küçük ve Orta Büyüklükteki İşletmelerin Tanımı, Nitelikleri ve Sınıflandırılması Hakkında Yönetmelik" içerisinde yer alan işletme tanımlarında belirtilen personel sayıları dikkate alınarak yapılmıştır. Bu yöntemle işletmelerin \%35'i KOBI, \% 55'i ise MAKRO işletme olarak gruplanmıştır.

İncelenen işletmelerin sektörel dağılımı Çizelge 1, kent ve coğrafi bölge dağılımları ise Çizelge 2'de verildiği gibidir.

Çizelge 1. Ankete Katılan İşletmelerin Sektörel Dağılımı

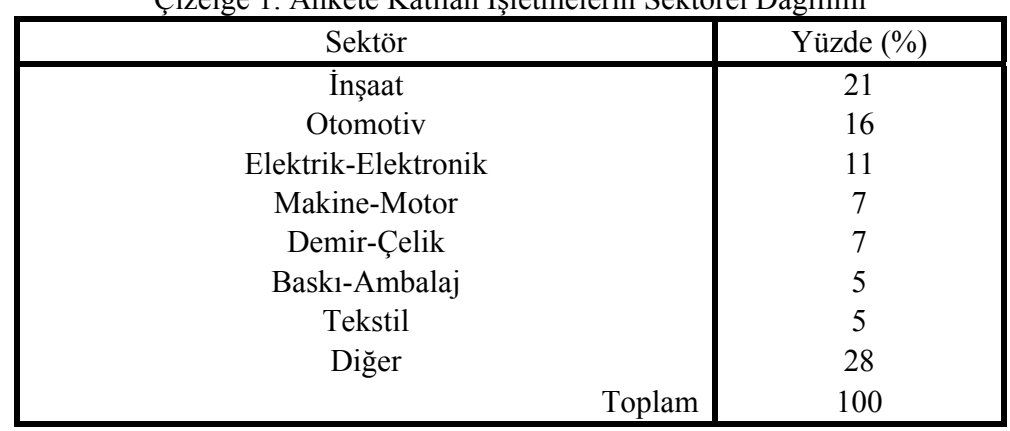


Çizelge 2. Ankete Katılan İşletmelerin Bulundukları Kent ve Coğrafi Bölgelere Göre Dağılımları

\begin{tabular}{|c|c|c|c|}
\hline Coğrafi Bölge & Yüzde (\%) & Kent & Yüzde (\%) \\
\hline \multirow{5}{*}{ Marmara } & \multirow{5}{*}{58,1} & İstanbul & 22,6 \\
\hline & & Bursa & 12,9 \\
\hline & & Gebze-Kocaeli & 12,9 \\
\hline & & Tekirda ̆ & 8,1 \\
\hline & & İzmit & 1,6 \\
\hline \multirow{4}{*}{ İç Anadolu } & \multirow{4}{*}{20,9} & Ankara & 12,9 \\
\hline & & Eskişehir & 4,8 \\
\hline & & Aksaray & 1,6 \\
\hline & & Kayseri & 1,6 \\
\hline \multirow{3}{*}{ Ege } & \multirow{3}{*}{16,2} & İzmir & 8,1 \\
\hline & & Manisa & 6,5 \\
\hline & & Afyon & 1,6 \\
\hline Akdeniz & 1,6 & Mersin & 1,6 \\
\hline Karadeniz & 1,6 & Düzce & 1,6 \\
\hline Belirtilmeyen & 1,6 & Belirtilmeyen & 1,6 \\
\hline Toplam & 100 & Toplam & 100 \\
\hline
\end{tabular}

1. İşletmelerin ISO 14001 CYYS Belgesi Alma Amaçları ve Amaçlarına Ulaşabilme Durumları: verilmiştir.

Amaçlarla ilgili olarak elde edilen veriler Çizelge 3, ulaşabilme başarı oranları da Çizelge 4'de

Çizelge 3. ISO 14001 Sertifikalandırma Sebeplerinin İșletme Sayısına Göre Frekans ve Yüzde Dağılımları

\begin{tabular}{|l|c|c|}
\hline \multicolumn{1}{|c|}{ Nedenler } & Frekans & Yüzde (\%) \\
\hline Ulusal ve uluslararası piyasada tercih sebebi olması & 59 & 95,2 \\
Firmanın rekabet gücünü artırmak & 58 & 93,5 \\
Çevreye duyarlı faaliyetlere önem vermek & 54 & 87,1 \\
Sağladığı faydalardan dolayı & 53 & 85,5 \\
Müşteri memnuniyetini artırmak & 52 & 83,9 \\
Çevre sorumluluklarını yerine getirip, yasal teşviklerden yararlanma & 43 & 69,4 \\
İşverenlerin talebi & 2 & 3,2 \\
İşletme grubu kararı & 1 & 1,6 \\
Çalışanlarda ve toplumda çevre bilincini artırmak & 1 & 1,6 \\
Uygulamada gereklilik & 1 & 1,6 \\
Ortak istek & 1 & 1,6 \\
\hline
\end{tabular}

Çizelge 4. İşletmelerin ISO 14001 ÇYS Kurma Amacına Ulaşıp Ulaşamama Sorgusuna Yanıtlarının Dağılımları

\begin{tabular}{|c|c|c|}
\hline Yanit & Frekans & Yüzde (\%) \\
\hline Evet tamamen & 41 & 66,1 \\
\hline Kismen & 19 & 30,6 \\
\hline Yanitsız & 2 & 3,2 \\
\hline Toplam & 62 & 100,0 \\
\hline
\end{tabular}

İşletmelerin ISO 14001 ÇYS'ni kurma amaçlarına ulaşıp, ulaşamamaları sorgusunda \%66'sının tam olarak, \%31'inin ise kısmen ulaştı̆̆1 tespit edilmiştir (Çizelge 4). Ankete katılan işletmeler tarafından "kısmen" seçeneğinde ulaşılamayan amaçlar olarak belirtilen yanıtlar değerlendirilmiş ve nedenlerine göre incelenerek Çizelge 3 'te yer alan seçenekler baz alınarak 3 grup altında şu şekilde toparlanmıştır: Çevreye duyarlı faaliyetlere önem vermek, firmanın rekâbet gücünü arttırmak ve çevre sorumluluklarını yerine getirerek yasal teşviklerden yararlanmak. Amaçlara ulaşılamamasına neden olduğu belirtilen sorunlar, temelde altyapı, donanım ve işletim yetersizliği şeklinde özetlenebilmektedir. 


\section{2. İșletmelerin Belgelendirilme Sürelerinin Dağıllımı:}

İşletmelerin ISO 14001 ÇYS belgesini alma sürelerinin dağılımları Çizelge 5'de sunulmuştur.

Çizelge 5. İşletmelerin Belgelendirme Sürelerine Göre Frekans ve Yüzde Dağılımları

\begin{tabular}{|c|c|c|}
\hline Belgelendirme süresi & Frekans & Yüzde (\%) \\
\hline 1-6ay & 23 & 37,1 \\
7-12ay & 25 & 40,3 \\
13-24ay & 8 & 12,9 \\
Yanitsiz & 6 & 9,7 \\
Toplam & 62 & 100,0 \\
\hline
\end{tabular}

\section{3. İșletmelerin Belgelendirme Kurulușlarının Akreditasyon Kaynakları:}

Belgelendirme kuruluşlarının akreditasyon menşei ile ilgili veriler Çizelge 6'da verilmiştir.

Çizelge 6. İşletmeleri Belgelendiren Kuruluşların Akreditasyon Durumu

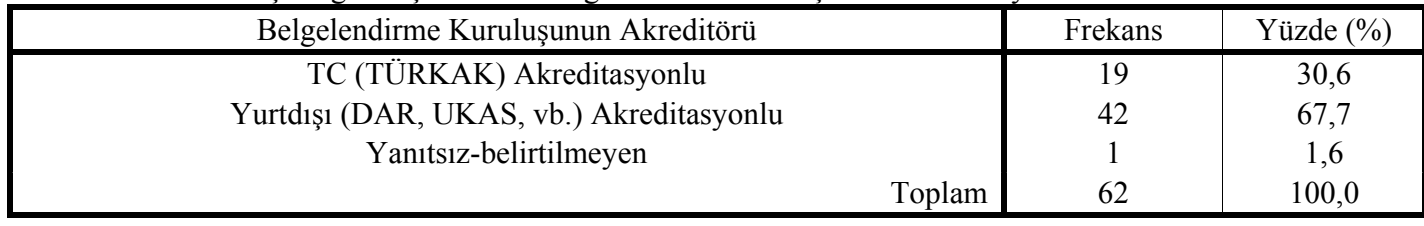

\section{4. İșletmelerin Belgelendirme Sürecinde Dıșarıdan Danıșmanlık Hizmeti Alma Durumları:}

Yapılan anket çalışması sonucunda katılımcıların \%67,7'sinin dışarıdan danışmanlık hizmeti alırken, \%30,6'sınn almadığı ve yalnızca 1 işletmenin soruyu yanıtsız bıraktığı görülmüştür. Aşağıda yer alan Çizelge 7'de hizmetin gerekliliği sorgusunun değerlendirmesi verilmiştir. Çizelge 8'de ise yalnızca bu hizmeti alan işletmelerin verdiği yanıtlar dikkate alınarak elde edilen yeterlilik değerlendirmesi sonuçları verilmiştir.

Çizelge 7. İşletmelerin Dış Danışmanlık Hizmeti Alma Gerekliliği Konusundaki Yanıtlarının Dağılımı

\begin{tabular}{|c|c|c|}
\hline Yanit & Frekans & Yüzde (\%) \\
\hline Evet, kesinlikle gerekli & 26 & 41,9 \\
\hline Hayır, kesinlikle gereksiz & 4 & 6,5 \\
\hline Alınsa da olur alınmasa da & 16 & 25,8 \\
\hline Diğer 1: Çalışanların bilgisi, kuruluşun bilgi birikimine bağlı & 10 & 16,1 \\
\hline Diğer 2: Yararlı, fakat şart değil & 5 & 8,1 \\
\hline Yanitsız & 1 & 1,6 \\
\hline Toplam & 62 & 100,0 \\
\hline
\end{tabular}

Çizelge 8. İşletmelerin Dışarıdan Alınan Danışmanlık Hizmeti Yeterliliği Konusundaki Yanıtlarının Dağılımı

\begin{tabular}{|c|c|c|}
\hline Yanıt & Frekans & Yüzde (\%) \\
\hline Evet, yeterli & 27 & 43,5 \\
Hayır, yetersiz. Çünkü...... & 14 & 22,6 \\
Yanıtsız & 21 & 33,9 \\
& 62 & 100,0 \\
\hline
\end{tabular}




\section{5. İșletmelerin Atık Türleri:}

Çizelge 9.'daki sonuçlar işletmelerin çok büyük oranda tehlikeli atık sorunu olduğunu göstermiştir.

Çizelge 9. Atık Türleri Açısından Katılımcı İşletmelerin Dağılımı

\begin{tabular}{|c|c|c|}
\hline Atık Türü & Frekans & Yüzde $(\%)$ \\
\hline Tehlikeli, kontamine, tıbbî atık gibi türleri de içeren & 58 & 93,5 \\
\hline Tehlikeli, kontamine, tıbbî atık gibi türleri içermeyen & 2 & 3,2 \\
\hline Yanits1z & 2 & 3,2 \\
\hline Toplam & 62 & 100,0 \\
\hline
\end{tabular}

6. İșletmelerin Doğrudan Standard'ın Kendisi ile İlișkilendirdiği Aksaklıklar:

$\mathrm{Bu}$ sorgulama sonuçlarının verildiği Çizelge 10 'da görüldüğü gibi katılımcıların yarısına yakın kısmı soruyu yanıtsız bırakmış, yanıtların en büyük bölümü ise uygulama sorunları üzerinde yoğunlaşmıştır.

Çizelge 10. İşletmelerin TS-EN-ISO 14001 Standardının Aksayan Yönleri Hakkındaki Görüşlerinin Dağılımları

\begin{tabular}{|c|c|c|}
\hline Belirtilen Aksaklıklar & Frekans & Yüzde (\%) \\
\hline 2004 versiyonu ile eksiklik ve aksaklıklar giderildi & 5 & 8,1 \\
Standardın sektörel, ulusal ve/veya işletme ölçeğine özgü olmaması & 5 & 8,1 \\
Genel ifadelerin yoruma açı olması & 1 & 1,6 \\
Daha çok üretim sektörünün ihtiyaçlarını karşıllayan bir yapıda olması & 2 & 3,2 \\
Sürekli iyileştirme prensibinin, artan mâliyet nedeniyle, bâzen & 1 & 1,6 \\
uygulanamaması & 2 & 3,2 \\
Kavramların net olmaması & 3 & 4,8 \\
Uygulama zorlukları nedeniyle bir süre sonra kâğı üzerinde kalması & 11 & 17,7 \\
Standard ile değil, uygulamayla ilgili olabilen problemler & 4 & 6,5 \\
Aksaklık yok & 28 & 45,2 \\
Yanıt yok & 62 & 100,0 \\
\hline
\end{tabular}

Çizelge 10'da da görülebileceği gibi, belirtilen aksaklıkların \%11'i standardın kendisi ile değil uygulama ile ilgili sorunlardır. Problemler daha çok sistemin kurulum ve işletim aşamalarındaki problemler arasında bulunan atık bertarâfı, alt yapı eksikliği, resmî kurumların duyarlılığı, çevre bilincinin oluşturulması gibi hususlardır. Katılımcılar bahse konu problemleri bu bölümde de yineleyerek önemlerini bir kez daha vurgulamışlardır.

\section{ISO 14001 CYS'nin Kurulumundan Doğan Ek Mâliyetleri Karș1lama Süreleri:}

ISO 14001 ÇYS belgelendirilmesinden doğan ek maliyetlerin işletmelerce ne kadar sürede karşılandığını tespit edebilmek amacıyla yapılan sorgulamada, işletmelerin \%53'ünün ek maliyetle karşılaşmadığı belirlenmiştir.

Çizelge 11. Ankete Katılan İşletmelerin ISO 14001 Belgelendirme Ek Maliyetlerini Karşıllama Sürelerinin Dağıllımı

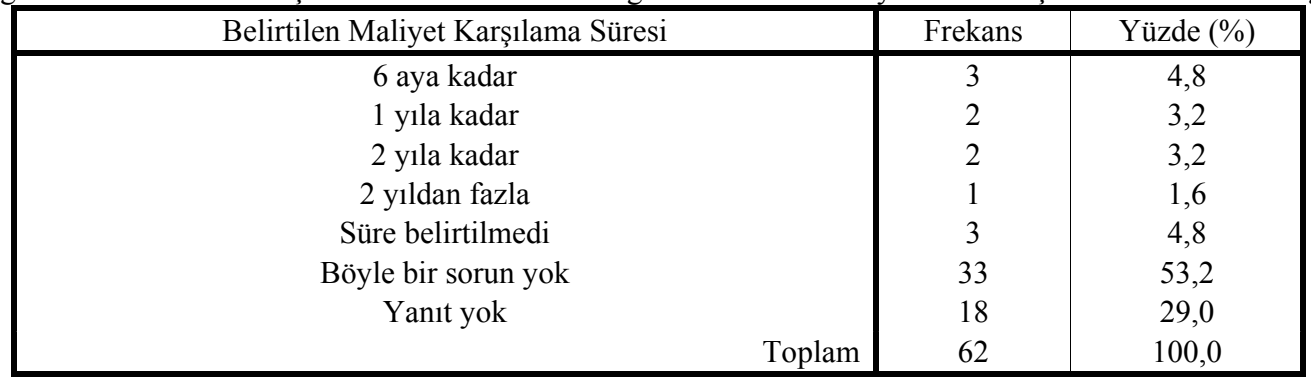




\section{ISO 14001 ÇYS Kurulumu ve İșletimi Dönemlerinde Karșılașıldığı Belirtilen Sorunlarla}

\section{Zorluklar:}

Uygulanan anket formunda karşılaşılmış olan sorun ve zorluklar, 1: Çok büyük ölçüde, 2: Büyük ölçüde, 3: Biraz, 4: Çok az, ve 5: Hiç şeklinde, baskınlık derecelendirmesine göre seçeneklendirilerek sunulmuştur. Elde edilen sonuçların baskınlık derecesi, frekans (F) ve yüzde (\%) değerleri olarak Çizelge 12 ve 13 'te gösterilmiştir. Ayrıca her bir seçenek için "personel sayısı" ve "sektör"ün etkileri, ek olarak "Atık bertarâfı konusunda lisanslı, uygun alan bulunmasında" ve "Geri dönüşüm faaliyetlerinde" karşılaşılan problemler sorgulamasında katılımcıların bulunduğu "kent" ve "coğrafi bölge"lerin etkileri de sorulmuştur . Bağımsız soruların birlikte değerlendirilmesinde, sorular arasındaki ilişkinin mevcudiyetinde anlamlılık düzeyi $\mathrm{p}<0.05$ olarak kabul edilmiştir. Etki analizlerinde anlamlı sonuçlar elde edilen seçenekler Çizelge 12 ve 13 'te koyu karakterlerle belirtilmiştir. Ayrıca incelenen işletmeler tarafından sorun yaşandığ 1 belirtilen atık türlerinin dağılımı da Çizelge 13 'ün en alt satırlarında verilmiştir.

Etki analizlerinde elde edilen, Çizelge 12 ve 13 'te koyu harflerle belirtilen anlamlı sonuçlar aşağıdaki şekilde irdelenebilir:

- Yasal ve diğer gereksinimlerin belirlenmesinde gözlenen sektörel etkiye göre; inşaat sektörünün genel olarak "biraz" zorlandığı, otomotiv yan sanayinin ise "büyük ölçüde" problem yaşadığ 1 ,

- Dokümantasyonun oluşturulmasında personel sayısının etki analizi sonuçlarına göre; hem makro hem de mikro işletme düzeyinde personele sâhip katılımcıların genel olarak "çok az" problem yaşadığı söylenebilir. Ancak frekans değerlerine bakıldığında, bu problemin makro işletme düzeyinde personeli olan katılımcılarca daha çok hissedildiği,

- Bilgiye ulaşımda personel sayısının etkinliği sorgulamasında; makro işletme boyutundaki katılımcıların genelde "çok az", mikro işletme personel sayısına sahip katılımcıların yanıtlarının ise "biraz" ve "hiç" derecelerinde yoğunlaştığı,

- Sertifikalandırma mâliyetleri üzerinde sektörel etki analizi sonucunda elde edilen anlamlı sonuçlara göre; inşaat sektöründe genel olarak "az" derecede problem yaşandığı,

- Geri dönüşüm faaliyetlerinde problem ve zorluk yaşanmasında, işletmelerin bulunduğu ilin etkisi; Ankara'da "büyük ölçüde", İstanbul ve Tekirdağ'da "biraz", Bursa'da "az" ölçüde olduğu,

- $\quad$ Standardın kullanım kolaylığı üzerinde personel sayısının etkin olduğu tespit edilmiştir. Buna göre, ÇYS standardının kullanımının kolay (kullanıcı dostu) olmadığı algılamasının KOBİ düzeyinde personel sayılarına sâhip işletmelerde daha çok hissedilen bir problem olduğu,

- KOBI'lere yönelik ÇYS bulunmamasından dolayı da sektörel etki analizinde; inşaat sektöründe önemli ölçüde problem ve zorluk yaşandığ 1

saptanmıştır. 
Çizelge 12. ISO 14001 ÇYS Kurulumunda Karşıllaşılan Sorun ve Zorlukların Baskınlık Dereceleriyle Frekans (F) ve Yüzde (\%) Dağılımları

\begin{tabular}{|l|c|c|c|}
\hline \multicolumn{1}{|c|}{ Karşılaşılan Problem ve Zorluklar } & Baskınlık Derecesi/leri & F & $\%$ \\
\hline Çevre boyutlanın tanımlanması ve derecelendirilmesinde & 2,3 & 55 & 89 \\
Yasal ve diğer gereksinimlerin belirlenmesinde & 2,3 & 50 & 81 \\
ÇYS Dokümantasyonunun oluşturulmasında & 3,4 & 46 & 74 \\
Çevre yönetim programının oluşturulup, uygulanmasında & 2,3 & 46 & 74 \\
Çevre politikasına uygun çevre amaç ve hedef belirlemede & 3,4 & 43 & 69 \\
En azından kritik pozisyonlara bilgili personel temininde & 3,4 & 42 & 68 \\
Eğitim ihtiyaçlarının tespiti ve eğitimlerin düzenlenmesinde & 3,4 & 39 & 63 \\
Bilgiye ulaşımda & $3,4,5$ & 35 & 57 \\
Finansal kaynak eksikliğini gidermede & 4,5 & 33 & 53 \\
Görev tanımlarını oluşturma, yetki ve sorumlulukları tanımlamada & 4,5 & 32 & 52 \\
Çevre politikasının belirlenmesinde & 4,5 & 31 & 50 \\
Sertifikalandırma mâliyetlerini karşılamada & $3,4,5$ & 29 & 47 \\
Teknik imkânların/altyapının yetersizliği & 4,5 & 28 & 45 \\
Belgelendirme kuruluşunun bulunmasında & 5 & 12 & 19 \\
Diğer: Atık yönetim sisteminin oluşturulmasında & 2 & 1 & 2 \\
Diğer: Bürokratik engellerin aşılmasında & 2 & 1 & 2 \\
Diğer: Personelde çevre bilincinin oluşturulmasında & 2 & 1 & 2 \\
\hline
\end{tabular}

Çizelge 13. ISO 14001 ÇYS İşletimi Aşamasındaki Sorun ve Zorlukların Baskınlık Dereceleriyle Frekans (F) ve Yüzde (\%) Dağılımları

\begin{tabular}{|c|c|c|c|}
\hline Karşılaşılan Problem ve Zorluklar & Baskınlık Derecesi/leri & $\mathrm{F}$ & $\%$ \\
\hline Devletin ve resmî kurumların destek ve teşviklerinin yetersizliği & 1,3 & 50 & 81 \\
\hline Çevre ile ilgili konularda alt yapı yetersizliği & $1,3,4$ & 47 & 76 \\
\hline Çevreye duyarlı faaliyetlerin uygulanmasında toplumun ve çalışanların duyarsızlığı & 3,4 & 46 & 74 \\
\hline Yeterli eğitim ve çevre bilincinin olmaması & 3 & 45 & 73 \\
\hline Çevre ölçümlerinin yaptırılması ve maliyetlerinin karşılanmasında & 2,3 & 44 & 71 \\
\hline${ }^{+}$Atık bertarafinda lisanslı, uygun alanların bulunmasında & 1 & 44 & 71 \\
\hline Yasal mevzuatın uygulanmasında & 2,3 & 43 & 70 \\
\hline Geri dönüșüm faaliyetlerinde & 3 & 42 & 68 \\
\hline Sürdürülebilirlik kavramının uygulanmasında & 3,4 & 41 & 66 \\
\hline Çevresel faaliyetlerle ilgili harçların yüksek olması & 3 & 39 & 63 \\
\hline Personelin yeniliklere karşı direnç göstermesi & 3 & 39 & 63 \\
\hline Faaliyetlere odaklanmak yerine denetim için dokümantasyona yönelmek & $3,4,5$ & 38 & 61 \\
\hline ÇYS amaç ve hedeflerinin küçük veya belirsiz tutulmuş olması & 4,5 & 38 & 61 \\
\hline Finansal kaynak eksikliği & $3,4,5$ & 34 & 55 \\
\hline Eğitim maliyetlerinin yüksek olması & $3,4,5$ & 33 & 53 \\
\hline Doküman ve kayıtların kontrolünde & 4,5 & 32 & 52 \\
\hline İç tetkik ve Yönetimin Gözden Geçirmesi (YGG) toplantılarında & 4,5 & 31 & 50 \\
\hline Danışmanlık ücretlerinin karşılanmasında & 4,5 & 29 & 47 \\
\hline Standardın kullanımı kolay (kullanıcı dostu) olmaması & 3,5 & 29 & 47 \\
\hline ÇYS amaç ve hedeflerinin çok yüksek tutularak gerçek dişı beklentilerde bulunulmuş olunması & 5 & 25 & 40 \\
\hline Kalibrasyon masraflarının yüksekliği & 5 & 24 & 39 \\
\hline KOBİ'lere yönelik ÇYS bulunmaması & 3,5 & 24 & 39 \\
\hline Üst yönetim ve yönetimin desteği hususlarında & 5 & 21 & 34 \\
\hline Cihaz kalibrasyonları için yetkili kalibrasyon laboratuvar(lar)ının bulunmasında & 5 & 20 & 32 \\
\hline Diğer: Yönetmeliklerin anlaşılmasında ve AB normlarına uyum için yüksek taleplerde bulunulmasında & 2 & 2 & 3 \\
\hline${ }^{+}:$Atık bertarafında özellikle problem yaşanılan atık türleri & $\mathrm{F}$ & \multicolumn{2}{|c|}{$\%$} \\
\hline Tehlikeli atıklar & 19 & \multicolumn{2}{|c|}{30,6} \\
\hline Kontamine ve tıbbî atıklar & 18 & \multicolumn{2}{|c|}{29,0} \\
\hline Atık Yağ & 2 & \multicolumn{2}{|c|}{3,2} \\
\hline Kontamine Atıklar & 1 & \multicolumn{2}{|c|}{1,6} \\
\hline Tıbbî Atıklar & 1 & \multicolumn{2}{|c|}{1,6} \\
\hline Boya Kutuları & 1 & \multicolumn{2}{|c|}{1,6} \\
\hline Filtre & 1 & \multicolumn{2}{|c|}{1,6} \\
\hline
\end{tabular}


9. İșletmelerin Problem ve Zorlukları CYS Kurulum ve İșletim Așamalarına Göre Ayrıștırması:

Belgelendirme sürecinde işletmelerin karşılaştıkları problem ve zorlukların, sistemin kurulum ve işletilmesi aşamalarına göre \%50 ağırlık bazında dağılımları Çizelge 14 'te verilmiştir. Görüldüğü üzere problem ve zorlukların işletme aşamasında daha çok yaşandığı tespit edilmiştir.

Çizelge 14. ISO 14001 Belgelendirme Sürecinde İşletmelerin Karşılaştıkları Problem ve Zorlukların Sistemin Kurulum ve İşletilmesi Aşamaları için \%50 Ağırlık Bazına Göre Yüzde Dağılımları

\begin{tabular}{|c|c|c|}
\hline Problem ve Zorlukların Kurulum ve İşletme Aşamalarına Göre Yüzde Dağılımları & Frekans & Yüzde $(\%)$ \\
\hline$\% 50$ 'den az kurulum, \%50'den fazla işletme aşamasında & 27 & 43,5 \\
\hline$\% 50$ 'den fazla kurulum, $\% 50$ 'den az işletme aşamasında & 16 & 25,8 \\
\hline \%50 kurulum, \%50 işletme aşamasında & 12 & 19,4 \\
\hline Yanitsiz & 7 & 11,3 \\
\hline Toplam & 62 & 100,0 \\
\hline
\end{tabular}

10. İșletmelerin CYYS Kurulumu ve İșletilmesinde Karșılaștığı Problem ve Zorlukları Assma Durumları: Karşılaşılan zorlukların aşılma oranları Çizelge 15 'teki gibidir. İşletmelerin \%54,8'inin sorunlarının yarıdan fazlasını çözebildikleri görülmektedir.

Çizelge 15. Katılımcıların Karşılaştıkları Problem ve Zorlukları Aşıma Durumlarının Yüzde Dağılımı

\begin{tabular}{|c|c|c|}
\hline Problem ve Zorlukların Aşılma Dağılımları & Frekans & Yüzde $(\%)$ \\
\hline$\% 50$ 'den az & 1 & 1,6 \\
\hline$\% 50$ 'den fazla & 34 & 54,8 \\
\hline$\% 50, \% 50$ & 2 & 3,2 \\
\hline Yanits1z & 25 & 40,3 \\
\hline Toplam & 62 & 100,0 \\
\hline
\end{tabular}

Katılımcıların belirttiği aşılamayan problem ve zorluklar, daha çok firma tarafindan vurgulanma hassasiyetine göre değerlendirilmiştir. Çizelge 16.a'da belirtilme frekansı (BF)>1 olanlar, Çizelge 16.b'de ise $\mathrm{BF}=1$ olanlar sunulmuştur.

Çizelge 16.a. Katılımcıların Belirttiği Aşılamayan Problem ve Zorluklardan Belirtilme Frekansları (BF)>1 Olanlar.

\begin{tabular}{|l|c|}
\hline \multicolumn{1}{|c|}{ Aşılamayan Problemler } & BF $>1$ \\
\hline Atıkların bertarafı ve geri kazanılması konusunda teknoloji, tesis, taşıma araçları vb. yetersizliği & 6 \\
Tehlikeli atıkların bertarafında İzaydaş dışında alternatif olmaması ve İzaydaş'ın atık alımını durdurması & 5 \\
Çalışanların çevreye duyarlılık ve bilincinin yaratılıp arttırılmasıda eğitimlerin yetersizliği & 5 \\
Yeni çıkan ve değişen yasal zorunluluklara adaptasyonda ve karşılanmasında & 2 \\
Yeni açılan şubelerde ÇYS'nin kurulum ve işletilmesinde & 2 \\
Atıkların özellikle de az miktardaki tehlikeli atıkların bertarafı için maliyetlerin yüksek olması & 2 \\
\hline
\end{tabular}


Çizelge 16.b. Katılımcıların Belirttiği Aşılamayan Problem ve Zorluklardan Belirtilme Frekansları (BF)=1 Olanlar.

\begin{tabular}{|c|c|}
\hline Aş1lamayan Problemler & $\mathrm{BF}=1$ \\
\hline $\begin{array}{l}\text { Çevre Bakanlığı'nın Mevzuatta yer alan uygulama/kısıtlamalar konusundaki yaptırım gücü düşüklüğü } \\
\text { nedeniyle ÇYS kurmanın özellikle KOBİler için mâliyet arttırıcı unsur olması } \\
\text { Yasal izinlerdeki gecikmeler } \\
\text { Üretim prosesinin teknolojik seviyesi, teknik imkânların yetersizliği } \\
\text { Çalışanların devir hızı } \\
\text { ÇYS’nin tüm şirketler ve alt yüklenicilerde çalışma kültürü olarak yaygın olmaması; bilgi, bilinç eksikliği } \\
\text { Yasal mevzuatların yönlendirici ve uygulanabilir olmaması } \\
\text { Bilinçlendirme ve bilgilendirmeye duyarsızlık } \\
\text { Sürekli iyileştirme prensibi uygulamasında teknolojik gelişmelerin yeterince izlenememesi } \\
\text { İç denetçilerin yeterli duyarlılığı gösterememesi } \\
\text { (YGG)'de aktif katılımın sağlanamaması } \\
\text { Teknolojik eksiklikler } \\
\text { Bürokrasi ve engelleme } \\
\text { Çalışanların yeniliklere adaptasyonunun sağlanamaması } \\
\text { Ambalaj Atıkları Yönetimi konusunda Bakanlık ile yaşanan görüş farklılığı } \\
\text { Sektörel belgelendirme problemi } \\
\text { Periyodik eğitimler ve bilinçlenme } \\
\text { Atıkların çalışanlar tarafından ayrıştırılması } \\
\text { Yıllık eğitim ve denetimlerin iyileştirilmesı } \\
\text { Hedeflerin daha somut hale getirilmesi } \\
\text { Bölgede tehlikeli atıkların bertarafını sağlayacak bir tesisin olmaması } \\
\text { Bölgesel altyapı eksiklikleri } \\
\text { Resmî kurumların bilgi eksikliği } \\
\text { Eğitimlerde genel bilinç düzeyi düşüklü̆g̈ü nedeniyle istenen başarının elde edilememesi } \\
\text { Türkiye'de ÇYS uygulayan firmalara tanınan ayrıcalık olmaması sonucu sektörel haksız rekabet } \\
\text { Uygulanması gereken idarî para cezalarının uygulanmaması, ya da caydırıcı olmaması } \\
\text { Yeni yatırımların devam etmesi } \\
\text { Çevre ölçümlerinin yaptırılamaması } \\
\text { Yöneticilerin desteği konusunda eksiklikler ve değişimi kolay kabul etmemeleri } \\
\text { Toplum bilincinin arttırılamaması }\end{array}$ & $\begin{array}{l}1 \\
1 \\
1 \\
1 \\
1 \\
1 \\
1 \\
1 \\
1 \\
1 \\
1 \\
1 \\
1 \\
1 \\
1 \\
1 \\
1 \\
1 \\
1 \\
1 \\
1 \\
1 \\
1 \\
1 \\
1 \\
1 \\
1 \\
1\end{array}$ \\
\hline
\end{tabular}

\section{1. İșletmelerin ISO 14001 Belgesini Calıștığ İșletmelerde Arama Durumları:}

Çizelge 17'de görüldüğü gibi işletmelerin ISO 14001 ÇYS belgesini çalıştı̆̆ işletmelerde aramaları ile ilgili yanıtları yoğun olarak "tercih sebebi" seçeneğinde toplanmıştır. Nedenler olarak politika, taahhüt, hedef ve prensiplerinde yer alması, bir rekâbet avantajı sağlaması, faâliyetlerin birbirini zincirleme olarak etkilemesi, çalışılan firma, ya da tedârikçinin çevreye duyarlı ve bilinçli olduğunu göstermesi, müşteri ve tedârikçinin talep etmesi, kuruluşun olumlu niteliklerini göstermesi gibi gerekçeler belirtilmiştir.

Belgenin aranmaması nedenleri olarak da çevre bilincine sâhip olmalarının kendileri ve çevrelerince yeterli görülmesi, bu belgeye sâhip firma sayısının azlığı, taşeronların henüz hazır olmaması, hizmetin satın alınmıyor olması ve malzemelerin yurt dışında üretiliyor olması gibi nedenler gösterilmiştir.

Çizelge 17. İşletmelerin Çalıştı̆̆ Diğer İşletmelerde veya Tedarikçilerinde ISO 14001 Belgesine Sahip Olma Koşulunu Arayıp Aramadıkları Sorgusunda Elde Edilen Yanıtların Dağılımı

\begin{tabular}{|c|c|c|}
\hline ISO 14001 Sertifikalandırmasının Diğer İşletmelerde Aranmasına Verilen Önem & Frekans & Yüzde \\
\hline $\begin{array}{c}\text { Evet mutlaka arıyoruz. Çünkü........ } \\
\text { Tercih sebebimizdir. Çünkü........ } \\
\text { Önemli değil, olmasa da olur. Çünkü........ } \\
\text { Hayır aramıoruz. Çünkü........ } \\
\text { Yanıtsız }\end{array}$ & $\begin{array}{c}8 \\
46 \\
1 \\
6 \\
1 \\
62\end{array}$ & $\begin{array}{c}12,9 \\
74,2 \\
1,6 \\
9,7 \\
1,6 \\
100,0\end{array}$ \\
\hline
\end{tabular}




\section{Tartışma}

Ankete katılan işletmelerin sektörel dağılımına bakıldığında, en çok katılım sağlanan sektörün inşaat sektörü olduğu görülmüştür. Bu tablonun inşaat firmalarının katıldıkları ihâlelerde ISO 14001 ÇYS belgesinin aranıyor olması göz önüne alınarak normal olduğu söylenebilir. Makro işletme personel sayısına sâhip işletmelerin, ISO 14001 ÇYS belgeli olma oranının, KOBİ personel sayısına sâhip işletmelerden yüksek olması, makro işletmelerin uluslararası piyasalarla ilişkilerinin yüksekliği ve mali kaynaklarının daha fazla olması gibi faktörlerle açıklanabilir. Kent bazında yapılan değerlendirmede, bekleneceği üzere katılımın en çok İstanbul'dan, coğrafi bölge bazında da Marmara Bölgesi'nden olduğu görülmüştür. $\mathrm{Bu}$ sonuç üzerinde endüstrileşme ve nüfus yoğunluğunun yüksekliği yanında, işletmelerin yönetişim, iletişim açısından gelişmişliklerinin en yüksek düzeyde oluşunun etkili olduğu düşünülebilir.

Katılan işletmelerin ISO 14001 ÇYS belgelendirmesini tercih nedenleri arasında en fazla; "ulusal ve uluslararası piyasada tercih sebebi olması" ve "firmanın rekabet gücünü artırmak" seçeneklerinin belirtildiği görülmektedir. Bu da gösteriyor ki firmaların ISO 14001 sahibi olması ulusal ve uluslararası piyasada onlara bir avantaj sağlamakta ve bu nedenle işletmeler tarafından talep edilmektedir. Bunun yanında "Çevre sorumluluklarını yerine getirerek yasal teşviklerden yararlanma" nedeninin ulaşılamayan amaçlar arasında yer alması üzerinde, işletmelerce de belirtildiği gibi Türkiye'deki yasal teşviklerin yok denecek kadar az olmasının etken olabileceği düşünülebilir. Ulaş1lamayan amaçlar kapsamında yer alan diğer iki husus ise "Çevreye duyarlı faâliyetlere önem vermek" ve "Firmanın rekâbet gücünü arttırmak" olmuştur. Bu amaçlara ulaşabilmek için ise başta yeterli çevre bilincinin sağlanabilmesi, bu amaçla işletme personeline yeterli ve kaliteli eğitimlerin en uygun kişilerce ve gereken düzeyde verilmesi esastır. Diğer bir etken, çevresel faâliyetlerin gerçekleştirilmesindeki zorluk ve problemlerdir. Atık bertaraf tesisleri gibi alt yapının sağlanması, yasal düzenleme ve teşviklerin de bu işletmelere destek olacak şekilde geliştirilerek uygulanması gerekmektedir.

Sektör farkı ve benzeri faktörleri gözetmeksizin yapılan belgelendirme süreci değerlendirmesi sonucunda katılımcı firmaların belgelerini $\% 40.3$ payla $7-12$ ay arasındaki bir sürede aldıkları görülmüştür. Bu sonuç Amerika'da Babakri ve arkadaşları (2003) tarafından yapılan çalışmadaki süreçle ilgili verilere paraleldir. Türk-AK ya da yurtdış1 akreditasyonlu kuruluşların belgelendirme süreci daha uzun, ya da kısadır denilemeyeceği için bu sürecin işletme yöneticilerinin tutumundan personelin eğitim düzeyine, işletmenin alt yapısına kadar birçok faktörden etkilenebildiği şeklinde yorumlanabilir.

Dışarıdan danışmanlık hizmeti alımına işletmelerin personel sayılarının etkisinin olduğu tespit edilmiştir (Mındıkoğlu, 2007). Elde edilen sonuçlara göre KOBİ'lerin dışarıdan danışmanlık hizmeti alma oranının daha yüksek olduğu tespit edilmiştir. Stratejik SME Grubu (2005) tarafindan yapılan çalışmada da ayni sonuç belirtilmiştir. Bunun yanında INEM'in (2006) Avusturya, Macaristan, Slovak Cumhuriyeti ve Tayland'daki uzmanlar arasındaki araştırması da işletmelerin dışarıdan danışmanlık hizmeti alınmadığında zorlandıklarını göstermiştir. Kalitesiz danışmanlık hizmetinin işletmeye verebileceği zararlar göz önünde bulundurularak, hizmete gerek duyulduğu taktirde, en yararlı olabilecek kaynaktan ve doğru şekilde alınmasının önemini vurgulamak gerekir.

Hizmetin yeterlilik sorgulamasında \%23'lük bir katılımcı oranının "Hayır, yeterli değil. Çünkü..." seçeneğini işaretlediği görülmüştür (Mındıkoğlu, 2007). Yanıtlarda belirtilen sebeplerden de hizmetin yeterliliğinin daha çok hizmeti veren tarafın kalite, bilgi ve deneyimi, salt ticâri amaç güdüp gütmemesine göre değişebileceği saptanmıştır (Çizelge 8). Danışmanlık hizmeti, hazır bir ÇYS'nin işletmeye monte edilmesi şeklinde değil, etkin bir iletişimle özümleme ve personelin etkin şekilde katılımı sağlanarak verilmelidir. İşletmeyi en iyi tanıyanların yönetim ve personeli olduğu hiçbir şekilde göz ardı edilmemelidir. Danışmanlık kalitesini arttırmak için hizmeti veren tarafa belli niteliklerin şart koşulması, tüm süreç boyunca denetlenmesi ve hizmet târifelerinin belirlenmesi gerekecektir. 
Türkiye'deki durumun tespiti için uygulanan anket çalışmasında literatürde yer alan sorunlar seçeneklendirilerek kullanılmıştır. Anket bulguları tüm bu problemlerin, değişik derecelerde olsa da ülkede yaşandığını göstermiştir. Aşağıda, "Bulgular" bölümünde sunulan verilerin diğer ülkelerde tespit edilenlerle kıyaslanarak değerlendirilmesine yer verilmiştir.

KOBİ'lerde çevre politikası eksikliği UNEP ve UNCTAD'ın (2000) yaptığ 1 araştırmada tespit edilmiş, ABD Liman Müdürlügü̈'ndeki çalışmada da yazılı çevre politikası eksikliğinin çevresel etkilerin azaltılmasını engelleyerek büyük sorunlara yol açtı̆̆ 1 belirlenmiştir (Rendell ve McGinty 2004). Çevresel boyut ve etki belirlenmesi eksikliğinin KOBİlerle ilgili olarak en çok karşılaşılan sorunların başında geldiği de belirtilmiştir (ISO/TC207/SC1/ Strategic SME Group, 2005). İtalya'da çevresel taban belirleme ve etki değerlendirmede bu konudaki yanlışlar özellikle çevre performansı açısından değerlendirilmiştir. Ancak çalışmada ÇYS'nin kendisine odaklanıldığından bu husustaki değerlendirmelere yer verilmemiştir (Ghisellinia ve Thurston, 2005). Amerika'daki bir araştırmanın sonuçlarına dayanılarak da çevresel etki boyutlarını belirlemenin karmaşıklığı nedeniyle çok titiz çalışılması gereği vurgulanmıştır (Babakri vd., 2003). Engel (2003) Belçika örneğinde çevre öğelerinin etki büyüklüklerinin belirlenmesindeki sorunları dile getirmiştir. Young ve Shuster (2006) Tayland örneğinde çevre unsurları belirlenmesindeki zorlukları tanımlamışlardır. Belirttikleri sorunlara bakıldığında daha çok kurulum aşamasında zorluk yaşandığı göze çarpmaktadır. Türkiye örneğini ele alan bu çalışmanın sonuçlarına göre ise problemler ağırlıkla uygulama aşamasında yaşanmaktadır. $\mathrm{Bu}$ durumda Tayland'da görülen problemlerin daha çok bilgi eksikliğinden, Türkiye'de yaşananların özellikle alt yapı yetersizliklerinden kaynaklandığı belirtilebilir.

Yasal gerekliliklerin tümünden haberdâr olma, gereksinimlerin tam ve doğru belirlenebilmesi çok önemli bir sorundur (INEM, 2006; ISO/TC207/SC1 2005). ISO/TC207/SC1 sorunun özellikle KOBİ'ler için önemini vurgulamıştır. Yüksel (2002) tarafından Türkiye için aynı sonuca varılmış olması ve burada sunulan çalışmada da yasal gerekliliklerin belirlenmesinin hâlen daha önemli bir problem olarak görülmesi dikkat çekicidir. $\mathrm{Bu}$ sonuç problemin çözümünde bir gelişme kaydedilemediğini göstermektedir.

Çevre politikasına uygun çevre amaç ve hedef belirlemede, çevre yönetim planlarının oluşturulup, uygulanmasında katılımcıların çok yoğun olmamakla birlikte problem yaşadıkları ortadadır. Uruguay'da yapılan çalışmada, dokümantasyona verilen önemin, temel amaç ve hedeflerin geliştirilmesini arka planda bıraktı̆̆ vurgulanmış (Malmborg 2006), Young ve Schuster (2006), Tayland'da çevre amaç ve hedeflerinin tanımlanmasında problem yaşandığını belirtmiş, Babakri ve arkadaşları (2003) da çevre yönetim programı, amaçları ve hedeflerinin oluşturulmasına dikkat edilmesi gerektiğinin üzerinde durmuştur. INEM'in 2006'da ÇYS uzmanlarıla yaptı̆̆ anket çalışmasında özellikle KOBİ'lerin ÇYS amaç ve hedeflerinin belirlenmesinde problem yaşadıkları belirtilmiştir. $\mathrm{Bu}$ sorunun işletme büyüklügünden çok işletme personelinin bilgi ve tecrübesiyle giderilebileceğini belirtmek yanlış olmayacaktır.

Malmborg (2006) Uruguay'da da görev tanımlarının oluşturulması, yetki ve sorumlulukların tanımlanması ve çevresel görev dağılımında yanlışlıklar yapıldığını vurgulamıştır. Kritik pozisyonlar için bilgili personel teminindeki problem, İngiltere ve diğer AB ülkeleri (Hillary 2004), INEM (2006) tarafından tespit edilmiş ve belirtilmiştir. Aynı problem UNEP ve UNCTAD (2000) tarafından özellikle KOBİ'ler için önemli görülerek vurgulanmıştır.

Yukarıda sunulan anket sonuçları, eğitim ihtiyaçlarının tespiti ve eğitimlerin düzenlenmesinde katılımcı işletmelerin genel anlamda fazla problemle karşılaşmadığını göstemekte, Babakri ve arkadaşları (2003), INEM (2006), ISO (2006), Yüksel (2002), Salihoğlu ve arkadaşları (2003) tarafından yapılan çalışmalardaki sonuçlarla paralellik göstermektedir.

Babakri ve arkadaşları (2003) tarafindan yapılan çalışmada elde edilen sonuçların prosedürler, tâlimat ve formlar gibi dokümantasyonun oluşturulmasında problem yaşandığını göstermiş olması, bu çalışmada elde edilen sonuçla uyumludur. UNEP ve UNCTAD'ın (2000) yaptığı çalışmada bilgiye ulaşımda KOBİ'lerde daha çok problem yaşandığ 1 vurgulanmıştır. Her ne kadar burada sunulan ankete katılan işletmelerce bu konuda çok fazla problem yaşanmadığ belirtilmiş olsa dahî, etki analizinde 
KOBİ'lerin bu problemle karşılaşma ve zorluk yaşama dereceleri diğer işletmelere göre biraz daha yüksek çıkmıştır. Bu sonuçlar literatürdeki bulgularla uyumludur.

Atıcı (1999) makâlesinde belgelendirme firmalarının yokluğunu, özellikle gelişmekte olan ülkeler için önemli bir sorun olarak değerlendirmiştir. Ancak gelişmekte olan ülke konumundaki Türkiye'de yapılan çalışmamızda, bu problemin hemen hemen tümüyle aşıldığını gösteren sonuçlar elde edilmiş olması, bu konudaki ilerlemenin göstergesi olarak sevindiricidir.

Finansal kaynak yetersizliğinin Amerika'da (Babakri vd. ,2003), Belçika'da (Engel ,2003), Uruguay'da (Malmborg, 2006), ayrica da INEM (2006) ile UNEP ve UNCTAD'in (2000) çalışmalarında, ISO'nun anket sonuçlarında olduğu gibi Türkiye'de (Yüksel, 2002) yapılmış araştırmalarda belirtilmiş olmasına dayanarak finansal kaynak sıkıntısının hemen hemen tüm ülkelerde yaşandığı belirtilebilir. Burada sunulan çalışmadaki katılımcıların yoğunlukla yurt dışı merkezli işletmeler olduğu göz önünde tutulursa çıkan sonuçlar normal karşılanabilir.

Araştırmamızda olduğu gibi, Uruguay için de teknik altyapının yetersizliğinden söz edilmektedir (Malmborg, 2006). Yüksel'in (2002)'de belirttiği çevreyle ilgili konulardaki alt yap1 yetersizliğinin işletmelerin önemli bir sorunu olması durumunun sürdüğü görülmektedir. En çok önem verilmesi gereken konulardan biri olmasına karşın anket sonuçları henüz bu konuda ilerleme kaydedilemediğini göstermektedir. Engel (2003) Belçika'da küçük fonların yetersizliğinin KOBİ’ler için önemli bir sorun olarak belirtmiş, Yüksel de (2002) Türkiye için aynı noktaya değinmiştir. Yüksel'in de belirlediği gibi, Türkiye'de bu fonların yok düzeyinde oluşunun etkisiyle, genelde tüm işletmelerin sıkıntısı sürmektedir.

Literatürde Hillary (2004) İngiltere ve diğer AB ülkeleri, Budak ve arkadaşları (2004) Çin, Malmborg (2006) Uruguay'da, UNEP ve UNCTAD (2000), ISO/TC207/SC1/ Stratejik KOBİ Grubu (2005) da örneklerinde ISO 14001 belgelendirme mâliyetlerinin KOBİ’ler için önemli bir sorun olduğunu belirtmişlerdir. Anketimiz ek belgelendirme mâliyetleri süreci sorgulamasında katılımcıların,genel anlamda böyle bir sıkıntı yaşamadıkları, ya da yurtdışı merkezli oldukları için bu sürece dikkat etmedikleri ortaya çıkmıştır.

İtalya'da Ghisellinia ve Thurston (2005), Uruguay'da Malmborg (2006) ve INEM'in çeşitli ülkelerdeki uzmanlara yönelik olarak yaptığ 1 anket çalışmasında (2006), denetim öncesinde dokümantasyon konusuna yoğunlaşarak diğer faâliyetleri ikinci plana atma probleminin var olması, bu problemin değişik özelliklerdeki ülkelerde de yaşandığını göstermektedir.

Babakri ve arkadaşları (2003), Malmborg (2006), UNEP ve UNCTAD (2000), ISO/TC207/SC1/ Stratejik KOBİ grubu (2005) ve ISO (2006) çalışmalarında finansal kaynak eksikliği sorununa yer vermişlerdir. Bu çalışmada, ankete katılan işletmelerin önemli bir kısmı yurt dışı merkezli olduğundan, bu sorun çok ön plana çıkmamıştır. Fakat sistemin kurulum ve işletim aşamalarında az da olsa yaşandığı tespit edilmiştir.

İşletmelerdeki cihazların kalibrasyonu ve kalibrasyon masraflarını karşılama sorunlarının boyutu cihaz sayı ve tipine göre değişim göstermektedir. Özellikle hizmetin yurtdışından alınması gerektiğinde, KOBİ'ler için sorun yaratacağ 1 (Atıc1, 1999), bu işlemlerin genelde problem yarattığ1 (Yüksel, 2002) belirtilmiştir. Her ne kadar KOBİ'lerin diğer işletmelere nazaran daha çok malî sıkıntı yaşaması beklense de, burada sunulan çalışma sonuçlarında görüldüğü gibi her KOBİ'nin mâlî açıdan mutlaka yetersiz olacağı genellemesi doğru değildir. Bu nedenle KOBİ yerine malî sıkıntıları olan işletmelerin varlığından söz edilmesinin daha yerinde olacağı ileri sürülebilir.

Babakri ve diğerlerinin (2003), INEM'in (2006), Srinivas'in (2006), ISO/TC207/SC1' in (2005), Salihoğlu ve arkadaşlarının (2003) yaptıkları çalışmalarda, ÇYS'nin başarısı ve etkinliği açısından büyük önem taşıyan üst yönetimin etkin desteği hususunda işletmelerde problem yaşandığı gözlemlenmiştir.

Yapılan çalışmada ve yararlanılan kaynakların hemen hemen hepsinde eğitimler, ya da çevre bilincinin oluşturulmasıyla ilgili problemlerin yaşandığının belirlenmesi bu sorunun çözüm bekleyen en önemli sorunlar arasında olduğu kanaatini uyandırmaktadır. Nitekim Ofori ve arkadaşları (2002), bilinçlendirme için ilgili kurum ve kuruluşların, medyanın tüm imkânlarından faydalanmasını 
önermektedir. Özellikle resmî kurumların medyayı kullanmasının toplumun bilinçlendirilmesine katkısının önemi üzerinde durulmalıdır.

Babakri ve diğerleri (2003), INEM (2006), UNEP ve UNCTAD (2000) ile Salihoğlu ve arkadaşları (2003) çalışmalarında personelin yeniliklere karşı direncine yer vermişlerdir. Çevreye duyarlı uygulamalarda toplum ve çalışanların duyarsızlığına Yüksel (2002) de önemli bir problem olarak yer vermiştir. Çalışan personel ve toplumun çevre duyarlılığ 1 ve bilincinin yeterli eğitimlerle sağlanması gerekmektedir.

Katılımcıların \% 94'ü tehlikeli, kontamine, tıbbî atık gibi atık türlerine sâhiptir. Elde edilen bulgulara göre, en önemli ve aşılamayan problemler arasında bu tür atıkların giderimi yer almaktadır (Çizelge 13). Daha önce de Erginel (2004) ve Yüksel (2002) de Türkiye'deki çalışmalarında atık bertarâfı ve geri dönüşümüyle ilgili işletmelerin yaşadığı problemin önemini vurgulamışlardır. Yatırım ve organizasyon konusu olan bu sorunun sürdüğü görülmektedir.

Ghisellinia ve Thurston (2005), (Malmborg, 2006), Delmas (2006), INEM (2006), UNEP ile UNCTAD (2000) ve Yüksel (2002)'in çalışmalarında, ayrıca ISO/TC207/SC1/ Stratejik KOBİ Grubu raporunda (2005) yasal mevzuatın karşılanmasında problem yaşandığının vurgulanmış olması, saptadığımız bahse konu problemin yaygınlığını göstermektedir.

Salihoğlu ve arkadaşlarının (2003) Bursa örneğinde elde ettikleri sonuçlara dayanarak belirttikleri hususlar arasında ÇYS dokümantasyonunun sürdürülebilirliğinde işletmelerin yaşadığı sorunların yer alması, bu problemin de bu süre zarfindaki devamlılı̆̆ının göstergesidir.

INEM'in uzmanlarla yaptığı anket (2006) ve UNEP ile UNCTAD'ın (2000) KOBI'ler arasında yaptığ 1 çalışmalarda KOBİ'lere yönelik özel bir ÇYS bulunmamasının da sıkıntı yarattığ1 belirtilmiştir. Hillary'nin (2004) İngiltere ve diğer AB ülkelerinde yaptığı araştırmada ve Engel'in (2003) Belçika'da yaptığı eko-haritalandırma çalışmasında da bu hususta problem yaşandığı bildirilmiştir.

Amerika'da Babakri ve arkadaşları (2003), İtalya'da Ghisellinia ve Thurston (2005) tarafindan yapılan araştırmalarda, Engel'in Belçika'daki eko-haritalandırma çalışmasında (2003) olduğu gibi Salihoğlu ve arkadaşlarının (2003) Bursa örneğinde de doküman ve kayıtların kontrolünün problem yarattığ1 bilgisi yer almaktadır. Engel (2003) eko-haritalandırmanın, özellikle dokümantasyon problemini aşmak için, oldukça faydalı bir araç olduğunu vurgulamaktadır. Bu görüşe katılmakla birlikte bu sistem için teknolojik alt yapının, ya da kalifiye personel ile birlikte bilgisayar sisteminin bulunması, ya da geliştirilmesi gerektiği ortaya çıkmaktadır.

INEM' in uzmanlarla yaptığı anket çalışması (2006) sonucunda ortaya çıkan diğer bir problem ise yüksek danışmanlık ücretleridir.

İşletmelerin yararlanabilmesi amacıyla literatür taramasında yararlanılan çalışmalarda yer alan ve yazarların genel anlamda ileri sürdükleri öneriler aşağıdaki gibi irdelenmiştir.

Hillary (2004) aynı koşullarda bulunmayan işletmeler arasındaki eşitsizliği aşabilmek amacıyla işletme ölçeği ve sektörüne özgü, daha ayrıntılı araştırma yapılmasını önermektedir. $\mathrm{Bu}$ noktada ölçeğe ve sektöre göre belirlenecek hususların daha özel, ölçek ve sektöre özgü rehberlik sağlayacağından faydalı olabileceği kanısına katılmamak mümkün değildir.

Malmborg (2006) problemlerin giderilmesi için bilinçli bir üst yönetim ile ulusal düzeye indirgenmiş ÇYS oluşturulmasını önermektedir. Üst yönetimin desteğinin çok önemli olduğu ÇYS'nde, ulusal düzeye indirgenmiş bir ÇYS'nin sistem gereksinimlerinin karşılanmasında kolaylık sağlayacağı düşünülebilir.

INEM'in (2006) çalışmasında, uzmanlar tarafindan problemlerin aşılabilmesi için sadece risk azaltımına değil, çevresel iyileştirmeye de odaklanılması, KOBİ'lere özgü ÇYS geliştirilmesi, net örnekler içeren yardımcı kitapların hazırlanması, standardın gereklilikleriyle ilgili detaylı alt gruplar oluşturulması, gerekliliklerle ilgili kontrol listelerinin kullanılması ve basamaklardan oluşan sertifikasyon şeması oluşturulması önerilmektedir.

Tüm bu öneriler irdelendiğinde sürekli iyileştirme prensibinin devamlılığını sağlayabilmek açısından çevresel iyileştirmeye odaklanmanın gerekliliği ortaya çıkmaktadır. Ölçeklere ve özellikle 
KOBİ’lere özgü ÇYS'nin gerekliliklerin uygulanmasında kolaylık sağlayacă̆ı, yardımcı kitapların bilhassa tecrübe ve bilgi eksikliğine sâhip işletmeler için faydalı olacağı açıktır. Kontrol listeleri ise yapılan uygulamalarda önemli tüm noktaların atlanmamasını sağlayacaktır. Sertifikasyon şemalarının da şemadaki basamakların neresinde bulunulduğunu ve nereye gidileceğini görsel olarak, daha net şekilde göstererek faydalı olacağı söylenebilir.

ABD örneğini inceleyen Delmas (2006) kurumsal promosyonun gerekliliğini savunmuştur. Resmî kurumların ISO 14001'e yönelik yapacağ1 bilinçlendirme girişimlerinin faydalı olacağı düşünülebilir.

ISO/TC207/SC1 (2005) raporunda problemlerin çözümü için ISO tarafindan işletmelerin faaliyet alanına özel ÇYS'leri düzenlenmesi önerilmiştir. Böylelikle, gereksiz dokümantasyon ve bürokrasiden kaçınılmış ve küçük ölçekli işletmelerin sübvansiyonlardan daha çok yararlanabilmesine katk1 sağlanmış olunacağ 1 öngörülmüştür. Alternatif olarak da işletmelerin kendilerine özel ÇYS'lerini oluşturarak ISO onayına sunmaları önerilmiştir. Daha küçük ölçekli ÇYS'lerinin geliştirilmesinin bazı ölçeklere ve ișletmelere özel problemlerin çözümünde yararlı olabileceği düșüncesi de tartışmaya değer bir konudur. Atıcı (1999) bu fikri daha önce ortaya atarak özellikle işletme ölçeğine göre ÇYS düzenlenmesinin yararlarını tartışmıştır.

Yüksel (2002) ISO 14001 hususunda işletmelerin problemlerinin çözümü için üst yönetimin desteği ve gerekli malî kaynağı sağlamasının gerekliliğini vurgulamıştır. Geri dönüşüm faaliyetlerinin etkin şekilde gerçekleştirilebilmesi için gerekli düzenlemelerin, tesis ve hizmetlerin yeterli sayı ve kapasitede, ayrıca gerekli konumlarda sağlanması gereksinimini, çevre bilincinin oluşturulup, geliştirilmesi gereğini de vurgulamıştır. Tüm bu hususlar, yukarıda da ilgili değerlendirmelerde vurgulandığ

Salihoğlu ve arkadaşlarının (2003) uygulamalı Bursa çalışmasında ise ISO 14001 ÇYS’nin faydasının yalnızca işletme çalışanlarına değil, tüm topluma olacă̆ 1 vurgulanarak, yasal düzenlemeler ve standart maddelerinin etkin araçlar olarak kullanılması gereğine dikkat çekilmiştir. Tüm toplumda çevre bilinci, kültürü ve vicdânının oluşturulması gerekliliği üzerinde de durulmuştur. Hiç kuşkusuz tüm topluma yarar sağlayan bu sistemin problem ve zorluklarının aşılmasında çevre bilincinin rolü yadsınamayacak derecede büyüktür.

\section{Sonuç}

Türkiye genelinde yapılan anket uygulamasından elde edilen analizlerin yukarıda sunulan sonuç ve diğer çalışmalarla karşılaştırılarak yapılan değerlendirmelerinden de görülebileceği gibi, ISO 14001 ÇYS belgeli işletmelerin sistemin kurulum ve işletim aşamalarında karşılaştıkları problem ve zorluklar diğer dünya ülkelerinde de yaşanmaktadır. Ancak tüm bu problemlerin hissedilme düzeyleri ile karşılaşılma derecelerinin incelenen örneklerde farklılıklar gösterdiği söylenebilir. Örneğin burada sunulan anket sonuçlarına göre, yukarıda da belirtildiği gibi, işletmeler Türkiye'de var olan alt yapı eksikliği dolayısıyla atık bertarâfı konusunda gelişmiş diğer ülkelere göre büyük sıkıntı yaşamaktadır.

Diğer yandan, gelişmiş ülkelerde büyük ölçüde aşılmış olsa da, gelişen ve alt yapı eksikliği olan ülkelerde özellikle KOBİ'ler için önemli olduğu belirtilen ISO 14001 ÇYS ek mâliyetlerinin karşılanması sorunu (UNEP, UNCTAD, 2000; ISO/TC207/SC1/ Strategic SME Group, 2005; ISO, 2006; Budak vd., 2004; Hillary, 2004; Malmborg, 2006) varken, araştırmamız Türkiye'de bu konuda resmî destekler olmamasına rağmen, kuruluşların daha az sıkıntı çektiğini göstermiştir. Bu nedenle genel olarak, literatür taramasında değişik ülkelerde yapılan araştırmalarda belirtilen problem ve zorluklarla, burada Türkiye için tespit edilenlerin örtüştüğü belirtilebilir. Ancak yapılan araştırmalarda incelenilen örneklem grubu yanında, işletme ölçeği, faâliyet alanı, bulunduğu ülkenin fiziksel, ekonomik, sosyal, bürokratik ve benzeri koşullarının da bu problem ve zorlukların hissedilme derecelerini ve karşılaşılma sıklıklarını etkilediği bir gerçektir. Belirtilen problem ve zorlukların bir kısmının sistemin işletim aşamasında zaman içerisinde çözüme ulaşacağı düşünülmektedir.

Yapılan çalışmada problem ve zorluklardan en baskın olanları çevre ile ilgili konulardaki alt yapı yetersizliği, atık bertarâfında lisanslı, uygun alanların bulunması ve devlet ile resmî kurumların 
destek ve teşviklerinin yeterli olmaması olarak tespit edilmiştir. Başta bu problemler ve diğerlerinin çözümleri için çevre bilincinin oluşturulması ve arttırılması çok önemli ve gereklidir. Çevreye olan duyarlılık ve bilinç üst yönetimden personele, topluma, resmî kurum ve yetkili mercîlerdeki üst düzey yöneticilere kadar herkese kazandırılmış olmalıdır. Ayrıca işletme içerisinde gerekli konularda kaliteli, ve yeterli eğitimlerin sağlanması kaçınılmaz bir gereklilik olarak görülmektedir. Personelin yetki ve sorumluluklarının en etkin şekilde dağıtılması da önemli bir husustur. Bunlara ek olarak, akredite olmuş bir sertifikalandırma kuruluşunun tercih edilmesi, gerektiği taktirde gereken yönde ve yeterli düzeyde bilgi ve tecrübeye sahip dış danışmanlık hizmetlerinin alınması ile iç denetimlerin kaliteli yapılması da yarar sağlayacaktır. Atıkların bertarâfı ve geri dönüşümü faaliyetlerinin gerçekleştirilmesinde gereken hassâsiyetin gösterilmesi şarttır. Devlet ve resmî kuruluşların bu doğrultuda öncelikler belirleyerek gerekli çevresel alt yapının oluşturulmasına ve mevcudun iyileştirilmesine, yeterli sayıda ve gereken yerlerde atık bertaraf ve geri dönüşüm tesisleriyle hizmetlerinin sağlanmasına, ÇYS'ni destekleyecek yönde ekonomik teşviklere ve yasal düzenlemelere gitmesi gerekmektedir.

İşletmelerin hâlen daha çözümleyemediği problemlerin de Çizelge 16.a ve Çizelge 16.b'de ayrıca belirtilmesi ile önemi vurgulanmaya çalışılmış ve özellikle bu hususlarda çözüm alternatiflerinin üretilmesine yol açılması hedeflenmiştir. Bu çalışmayla, işletmelerin yaşadığı problem ve zorlukları aşmalarına, en azından azaltmalarına yardımcı olunabilmesi amaçlanmıştır. Ayrıca ISO 14001 ÇYS'ni kurmayı düşünen veya kurulum aşamasında olan işletmelerin daha net düşüncelerle sistemin adaptasyonunda başarılı olmalarına katkı sağlanması hedeflenmiştir. Ek olarak çalışmayla, işletmelere ISO 14001 ÇYS ile ilgili kendi içlerinde yaşadıkları problemleri hem çalışmada yer alan örneklem gurubuyla, hem de literatürden derlenen dünya örnekleriyle kıyaslama imkanı sunulmuş olacaktır.

\section{Kaynaklar}

Atıcı, F. 1999. ISO 14001 Çevre Yönetim Standardı, İstanbul Teknik Üniversitesi. FBE. Yüksek Lisans Tezi. İstanbul.

Babakri, K. Bennett, R. Franchetti, M. 2003. Critical factors for implementing ISO 14001 standard in United. Journal of Cleaner Production $11: 749-752$.

Budak, F. Yüceer, A. Kekeç, S. 2004. ISO 14001: Belgelendirmenin Nedenleri Faydaları ve Maliyeti. Yöneylem Araştırmasi/Endüstri Mühendisliği - XXIV Ulusal Kongresi, Gaziantep - Adana.

Cevilan, I. 2003. Çevre Yönetim Sistemleri (ISO 14000 Standartları) ve Kağıt Sanayinde Uygulanması, Balıkesir Üniversitesi. FBE. Yüksek Lisans Tezi. Balıkesir.

Çelebi, Y. 1999. ISO 9002 Kalite Güvence ve ISO 14000 Çevre Yönetim Sistemlerinin Polimerik Şerit Elyaf Üretimine Uygulanması, Yıldız Teknik Üniversitesi. FBE. Yüksek Lisans Tezi. İstanbul.

Delmas, M. 2006. Barriers And Incentives to the Adoption of ISO 14001 By Firms in The United States, www.law.duke.edu/journals/delpf/articles/delpf11p1.htm.

Demirel, B. 2001. ISO 14000 Çevre Yönetim Sistemi ve Türkiye'deki Uygulamaları, İstanbul Teknik Üniversitesi. FBE. Yüksek Lisans Tezi. İstanbul.

Demirhan, N. 2002. ISO 14001 Çevre Yönetimi Standartlarının Bir Un Fabrikasına Uygulanması, Gazi Üniversitesi. FBE. Yüksek Lisans Tezi.Ankara.

Doğan, C. 2002. ISO 14000 Çevre Yöneti Standartları ve Bir Petrol Dağıtım-Satış İstasyonundaki Uygulamas1, Gazi Üniversitesi. FBE. Yüksek Lisans Tezi. Ankara.

Engel, H. 2003. EMAS and ISO 14001 easy : 10 people, 10 pages , 10 days Small Management Tools for Micro-enterprises. INEM. ww.telarc.co.nz/info_sheets/te2.pdf. 
Erdağ, E. 2000. Cam Endüstrisinde ISO 14001 Uygulamaları, İstanbul Teknik Üniversitesi. FBE. Yüksek Lisans Tezi. İstanbul.

Erginel, N. 2004. ISO 14001 neler kazandırıyor? Dünyada Çevre Yönetim Sistemi uygulayan kuruluşların kazanımları neler?. Doğa ve Çevre Dergisi 8: 8 - 9.

Ghisellinia, A. Thurston, D. 2005. Decision traps in ISO 14001 implementation process: case study results from Illinois certified companies. Journal of Cleaner Production 13: 763 - 777.

Hillary, R. 2004. Environmental management systems and the smaller enterprise. Journal of Cleaner Production $12: 563-567$.

International Network for Environmental Management (INEM). 2006. Environmental Management Experts Identify Obstacles to ISO 14001 Implementation in SMEs and Suggest Ways to Overcome Them. www.inem.org/htdocs/iso/iso-sme.html.

ISO. 2006. ISO Poll. http://ems-hsm.com/Implementation/Impl_Pools.htm.

ISO/TC207/SC1/ Strategic SME Group. 2005. The Global Use of Environmental Management System by Small and Medium Enterprises. www.iso.org/tc207/sc1.

Karali, K. 2002. Çevre Yönetim Sistemi: Gıda Sanayi İşletmeleri İçin Rehber, Gazi Üniversitesi. FBE. Yüksek Lisans Tezi. Ankara.

Karakaş, N. 2002. Çevre Muhasebesi Uygulamaları, Muhasebecilerin Çevresel Sorunlara Karş1 Tutumları ve ISO 14001 Belgeli Kuruluşlarda Bir Araştırma (Kimya İlaç Sektörü), İstanbul Üniversitesi. SBE. Yüksek Lisans Tezi. İstanbul.

Malmborg, A. 2006. ISO 14001 in Uruguay - Problems and Opportunities: 3 - 46, exepsilon.slu.se/archive/00000582/.

Mındıkoğlu, B. 2007. "ISO 14001 ÇYS Standardı: İşletmelerin Karşılaştıkları Problem Ve Zorluklar Üzerine Bir Araştırma”. Ankara Üniversitesi. SBE. Sosyal Çevre Bilimleri Anabilim Dalı. Yükseklisans Tezi. Ankara : 170 - 185. http://acikarsiv.ankara.edu.tr/fulltext/2537.pdf.

Odabaş1, E. 2001. Sanayide Temiz Üretim İçin Çevre Yönetimi: Tekstil Sektöründe Uygulama Örneği, Mersin Üniversitesi. FBE. Yüksek Lisans Tezi. Mersin.

Ofori, G. Gang, G. Briffett, C. 2002. Implementing environmental management systems in construction: lessons from quality systems. Building and Environment $37: 1405$.

Polat, B. 2003. Çevre Yönetim Sistemi Uygulamalarının İşletmelere Sağladığı Faydalar: Bir Örnek Çalışma, Çukurova Üniversitesi. FBE. Yüksek Lisans Tezi. Adana.

Rendell, E. McGinty, K. 2004. Sample EMS Manual Environmental Management System Model Manual Specific to Pennsylvania Municipal Operations. Pennsylvania Department of Environmental Protection B -9 : 2-4.

Salihoğlu, G. Acar, V. Salihoğlu, K. 2003. Bursa Endüstrisinde ISO 14001 Çevre Yönetim Sistemi Uygulamaları. Çevre Bilim \& Teknoloji 1 (4) : $32-35$.

Srinivas, H. 2006. Problems Faced in Implementing the ISO 14001. Urban Environmental Management Info Sheet, http://www.gdrc.org/uem/iso14001/info-8.html.

Tuna, E. 2003. ISO 14000 Çevre Yönetim Sistemleri ve Bir Otomotiv Yan Sanayii Uygulamas1, Dokuz Eylül Üniversitesi. SBE. Yüksek Lisans Tezi. İzmir.

Tunca, T. 2001. Bir İlaç Endüstrisinde Çevre Yönetim Sistemi Uygulaması, Boğaziçi Üniversitesi. ÇBE. Yüksek Lisans Tezi. İstanbul.

Tütün, K. 2000. Çevre Yönetim Sistemi: ISO 14000 Çevre Yönetim Sistemi ve Belgelendirilmesinin İşletmelere Sağladığı Faydaları ve Bir Uygulama, Marmara Üniversitesi, SBE. Yüksek Lisans Tezi. İstanbul.

Ulu, A. 2001. Bir Kablo Fabrikasında ISO 14000 Uygulamaları, Boğaziçi Üniversitesi. ÇBE. Yüksek Lisans Tezi. İstanbul.

UNEP, UNCTAD. 2000. Trade, Environment and Development: ISO 14001 Standards for Environmental Management Systems. Train for Trade 2000. Module 6. 
Usta, R. 2001. Çevre Yönetim Sistemi ve ISO 14001 Standartları Doğrultusunda Bir Çay İşletmesindeki Çevre Boyut ve Etkilerinin, Amaç ve Hedeflerinin Program veya Programlarının Belirlenmesi, Gazi Üniversitesi. FBE. Yüksek Lisans Tezi. Ankara.

Uzun, B. 1999. ISO 14001 Çevre Yönetim Sisteminin Bir Elektronik Firmasında Kurulması, Dokuz Eylül Üniversitesi. FBE. Yüksek Lisans Tezi. İzmir.

Young, S. Schuster, M. 2006. How Can It Benefit Business? A Survey of ISO 14001 Certified Companies in Thailand. The Louis Berger Group, Inc. http://www.tei.or.th/main.htm.

Yüksel, H. 2002. Kalite ve Çevre Yönetim Sistemlerinin Bütünleştirilmesi: ISO 14000 Yaklaşımı, Dokuz Eylül Üniversitesi. SBE. İAD. Doktora Tezi. İzmir.

Zığındere, Y. 1999. Çevre Yönetim Sistemi ISO 14000 Standartları ve Arçelik A.Ş.'nde Bir Uygulama, Mimar Sinan Güzel Sanatlar Üniversitesi. SBE. Doktora Tezi. İstanbul.

25997 sayılı Resmi Gazete. 2005. Küçük ve Orta Büyüklükteki İşletmelerin Tanımı, Nitelikleri ve Sınıflandırılması Hakkında Yönetmelik. 